\title{
GLOSA CZĘŚCIOWO APROBUJĄCA DO UCHWAŁY NajWyższego SĄDU AdministracyjNego Z 17 LISTOPADA 2014 R., II FPS 3/14
}

„W stanie prawnym obowiązującym do dnia 31 grudnia 2013 r. wydatki na nabycie jednostek uczestnictwa w funduszach kapitałowych poniesione przez spadkodawcę podlegały odliczeniu przez spadkobiercę od przychodu z tytułu odkupienia przez fundusz inwestycyjny tych jednostek na podstawie art. 22 ust. $1 \mathrm{w}$ związku z art. 23 ust. 1 pkt 38 ustawy z dnia 26 lipca 1991 r. o podatku dochodowym od osób fizycznych (Dz.U. 2012 r. poz. 361 ze zm.).

Streszczenie. W artykule dokonano analizy i oceny wydanego przez NSA 17 listopada 2014 r. wyroku, który odnosił się do możliwości zaliczania do kosztów podatkowych przez spadkobiercę wydatków na nabycie jednostek uczestnictwa poniesionych przez spadkodawcę. Choć na aprobatę zasługuje korzystne dla podatników rozstrzygnięcie, to nie można zgodzić się z zasadnością całkowitego pominięcia odwołania się do ogólnych zasad sukcesji podatkowej skupiając się jedynie na przepisie materialnym.

Słowa kluczowe: glosa, wydatki na nabycie, koszty uzyskania przychodów, spadkobierca, spadkodawca

* Doktor habilitowany nauk prawnych, profesor nadzwyczajny w Katedrze Prawa Podatkowego na Wydziale Prawa i Administracji Uniwersytetu Łódzkiego, doradca podatkowy, adwokat, partner zarządzający w Mariański Group, współpracownik Centrum Dokumentacji i Studiów Podatkowych, członek zarządu polskiego oddziału Międzynarodowego Stowarzyszenia Podatkowego (International Fiscal Association), członek Europejskiego Stowarzyszenia Profesorów Prawa Podatkowego (European Association of Tax Law Professors) oraz Rady Programowej „Przeglądu Podatkowego”.

** Doktorantka w Katedrze Prawa Podatkowego na Wydziale Prawa i Administracji Uniwersytetu Łódzkiego, prawnik w Mariański Group Kancelarii Prawno-Podatkowej. Autorka bądź współautorka publikacji z zakresu prawa podatkowego. 
Wydana w listopadzie 2014 r. przez NSA w składzie siedmiu sędziów uchwała, mimo że dotyczy już częściowo nieobowiązującego stanu prawnego, ma duże znaczenie dla rozstrzygnięcia wątpliwości orzeczniczych. W glosowanej uchwale NSA jednoznacznie stwierdził, że w stanie prawnym obowiązującym do końca 2013 r. wydatki na nabycie jednostek uczestnictwa w funduszach kapitałowych poniesione przez spadkodawcę mogą podlegać zaliczeniu do kosztów uzyskaniu przychodów przez spadkobiercę. Zajęcie jasnego stanowiska przez NSA jest istotne, gdyż zdarza się, że do sądów wciąż trafiają sprawy odnoszące się do tego okresu. NSA argumentując swoje stanowisko powołał się na wyniki wykładni systemowej oraz funkcjonalnej co do jednolitego traktowania podatników podatku dochodowego uzyskujących podlegające opodatkowaniu dochody z omawianego źródła przychodów. Zwrócił również uwagę, iż biorąc pod uwagę znowelizowane od 1 stycznia 2014 r. przepisy, które jednoznacznie przyznają spadkobiercom możliwość takiego odliczenia, doszłoby do zróżnicowania znajdujących się w tej samej sytuacji podatników, gdyby na tle wcześniejszego stanu prawnego takiego prawa podatnikom odmówić. W uchwale pominięto natomiast, budzącą równie duże rozbieżności orzecznicze, kwestię zastosowania zasad wyrażonych w art. $97 \$ 1$ Ordynacji podatkowej ${ }^{1}$, stwierdzając, że do zasad tych należałoby się odwołać jedynie, gdy przepisy prawa materialnego nie pozwoliłyby na uznanie opisanych wydatków za koszt uzyskania przychodu.

\section{WYDATKI PONIESIONE NA NABYCIE JEDNOSTEK UCZESTNICTWA}

\section{A KOSZTY UZYSKANIA PRZYCHODU}

Definicja kosztów uzyskania przychodów zawarta jest w art. 22 ustawy z dnia 26 lipca 1991 r. podatku dochodowym od osób fizycznych ${ }^{2}$ i zgodnie z nią kosztami uzyskania przychodów są koszty poniesione w celu osiągnięcia przychodów lub zachowania albo zabezpieczenia źródła przychodów, z wyjątkiem kosztów wymienionych w art. 23 tejże ustawy. Posługując się tym pojęciem ustawodawca wskazał przesłanki jakie musi spełniać koszt

${ }^{1}$ Ustawa z dnia 29 sierpnia 1997 r. Ordynacja podatkowa, Dz.U. 2012.749 j.t. - dalej O.p.; Ordynacja Podatkowa.

2 Ustawa z dnia 26 lipca 1991 r. o podatku dochodowym od osób fizycznych, Dz.U. 2012.361 j.t. - dalej u.p.d.o.f. 
poniesiony przez podatnika, aby mógł być on przez niego brany pod uwage przy ustalaniu dochodu ${ }^{3}$. I tak, aby koszt mógł być uznany jako koszt uzyskania przychodów musi on:

1) służyć osiągnięciu przychodu, czyli został poniesiony w celu jego osiągnięcia lub zachowania albo zabezpieczenia źródła przychodów oraz

2) nie został wymieniony przez ustawodawcę w katalogu kosztów wyłączonych przez niego spośród kosztów uzyskania przychodów (art. 23 u.p.d.o.f.).

Zgodnie z obowiązującą do 31 stycznia 2013 r. regulacją art. 23 ust. 1 pkt 38 u.p.d.o.f., co do zasady nie uważało się za koszty uzyskania przychodów wydatków na objęcie lub nabycie udziałów albo wkładów w spółdzielni, udziałów (akcji) w spółce mającej osobowość prawną oraz innych papierów wartościowych, a także wydatków na nabycie tytułów uczestnictwa lub jednostek uczestnictwa w funduszach kapitałowych. W myśl tego przepisu wydatki takie są jednak kosztem uzyskania przychodu z odpłatnego zbycia tych udziałów (akcji), wkładów oraz innych papierów wartościowych, w tym z tytułu wykupu przez emitenta papierów wartościowych, a także $\mathrm{z}$ odkupienia tytułów uczestnictwa lub jednostek uczestnictwa w funduszach kapitałowych, albo umorzenia jednostek uczestnictwa, tytułów uczestnictwa oraz certyfikatów inwestycyjnych w funduszach kapitałowych, $\mathrm{z}$ zastrzeżeniem ust. $3 \mathrm{e}$.

Analizując treść przytoczonego przepisu, uznać należy, że wydatki na nabycie tych praw spełniają generalne przesłanki kwalifikacji jako koszty uzyskania przychodów. Ustawodawca poprzez takie sformułowanie treści art. 23 ust. 1 pkt 38 u.p.d.o.f. wprowadził jednak mechanizm odroczenia prawa do rozliczenia kosztów uzyskania przychodów. Mechanizm ten polega na umieszczeniu tych wydatków w katalogu wydatków nieuznawanych za koszty uzyskania przychodów, jednocześnie wprowadzając zastrzeżenie, że zakaz kwalifikacji tych wydatków jako koszt uzyskania przychodów ma charakter czasowy ${ }^{4}$.

$\mathrm{Na}$ podstawie przywołanego wyżej przepisu jednoznacznie można wywnioskować, że w przypadku umorzenia bądź odkupienia jednostek uczestnictwa w funduszach kapitałowych, wydatki na ich nabycie uważa się za koszty uzyskania przychodów. Problemy w orzecznictwie budziła natomiast możliwość uznania takich kosztów za koszty uzyskania przychodów

${ }^{3}$ W. Nykiel, A. Mariański (red.), Komentarz do ustawy o podatku dochodowym od osób fizycznych, Warszawa 2015, s. 465 i n.

${ }^{4}$ W. Nykiel, A. Mariański (red.), op. cit., s. 744 i n. 
w przypadku, gdy poniósł je spadkodawca. Należy zauważyć, że w art. 23 ust. 1 pkt 38 u.p.d.o.f. obowiązującego do 31 grudnia 2013 r. ustawodawca nie wprowadził ograniczenia, jakoby koszty poniesione $\mathrm{z}$ tytułu nabycia jednostek uczestnictwa mogły być rozpoznane wyłącznie u podmiotu, który takiego nabycia dokonał. Na tę kwestię zwrócili uwagę również M. Krajewski i K.G. Szymański w glosie krytycznej do wyroku z dnia 2 grudnia 2011 r. ${ }^{5}$, stwierdzając, że „art. 23 ust. 1 pkt 38 ustawy o podatku dochodowym od osób fizycznych nie wskazuje, kto ma prawo do potrącenia wydatków na nabycie jednostek uczestnictwa, co oznacza, że ex lege przysługuje ono każdemu posiadaczowi tych jednostek dokonującemu ich zbycia na rzecz funduszu inwestycyjnego w celu ich umorzenia".

Odmienne stanowisko było prezentowane w orzecznictwie sądów administracyjnych ${ }^{6}$, gdzie stwierdzano, że prawo do uznania wydatków poniesionych na zakup jednostek uczestnictwa jako kosztów uzyskania przychodów aktywuje się dopiero w momencie powstania przychodu z tytułu wykupu jednostek uczestnictwa oraz nie może być przedmiotem sukcesji. Przyjmując takie rozstrzygnięcia, sądy wskazywały, że kluczowe znaczenie ma ustalenie, kto z punktu widzenia podatkowego otrzymuje przychód ze zbycia jednostek uczestnictwa. Podmiotem tym, zdaniem sądów był podatnik (zbywca), który jest objęty obowiązkiem podatkowym. Sądy administracyjne stały na stanowisku, że skoro zbycie jednostek uczestnictwa w funduszach kapitałowych jest zdarzeniem faktycznym, które może nastąpić w przyszłości, to uprawnienie wynikające $\mathrm{z}$ omawianego przepisu ma charakter warunkowy i zależne jest od zdarzenia przyszłego i niepewnego. Uprawnienie to, zdaniem sądów, nie powstało $\mathrm{w}$ chwili nabycia jednostek uczestnictwa ani w chwili otwarcia spadku i nie zostało zainicjowane przez spadkodawcę w jakimkolwiek postępowaniu związanym z przedmiotowym uprawnieniem ${ }^{7}$.

Warto jednak zauważyć, że już przed wydaniem glosowanej uchwały zapadały wyroki korzystne dla podatników. I tak np. NSA w wyroku z 11 października 2013 r. ${ }^{8}$ stwierdził, iż uznanie, jakoby zbycie jednostek przez spadkobiercę miało charakter następczy, nie powiązany z realizacją określonego

${ }^{5}$ K.G. Szymański, M. Krajewski, Glosa do wyroku NSA z dnia 2 grudnia 2011 r., II FSK 2557/10., „Przegląd Podatkowy” 2012, nr 4, s. 39-49.

${ }^{6}$ M.in. w wyrokach z 10 lutego 2009 r., II FSK 1623/07; z 2.12.2011 r., IIFSK 2557/10; z 29.11.2012 r., II FSK, 737/11; z 2.10.2013 r. II FSK 2834/11.

${ }^{7}$ Zob. także glosę krytyczną: A. Mariański, Glosa do wyroku NSA z 2 grudnia 2011 r., II FSK 2557/10, „Glosa” 2013, nr 1, s. 107-111.

${ }^{8}$ Wyrok NSA z 11 października 2013 r., II FSK 2824/11. 
prawa majątkowego lub nawet ekspektatywy tego prawa jako przysługującego spadkodawcy, które mogłoby podlegać sukcesji na zasadach określonych art. $97 \$ 1$ Ordynacji podatkowej prowadziłoby do opodatkowania przychodu a w konsekwencji do dyskryminującego traktowania spadkobierców. NSA w glosowanej uchwale zwrócił uwagę, że taki tok rozumowania kłóci się $\mathrm{z}$ istotą podatków dochodowych, sprowadzającą się do obłożenia tą daniną dochodów, a nie przychodów. Brak natomiast w ustawie podatkowej wyraźnego wyjątku, pozwalającego na przyjęcie w omawianym przypadku - jako podstawy opodatkowania - przychodu, a nie dochodu.

$\mathrm{Na}$ uwagę i poparcie zasługują również inne tezy zawarte w wyżej przytoczonym wyroku. Otóż NSA podkreślił, że wykładnia językowa mogłaby prowadzić do wniosku, że spadkobierca nie ma prawa do uwzględniania wydatków poniesionych przez spadkodawcę na nabycie jednostek uczestnictwa. Sąd zwrócił jednak uwagę, że takie rozumowanie doprowadziłoby do naruszenia gwarantowanego przez Konstytucję $\mathrm{w}$ art. 21 prawa do dziedziczenia oraz prawa własności. Podobnie jak w glosowanym orzeczeniu, NSA odwołał się również do konieczności zastosowania wykładni systemowej i funkcjonalnej. Sąd zauważył, że przy przyjęciu negatywnej dla podatników interpretacji przepisów w tym zakresie doszłoby do nieuzasadnionego zróżnicowania sytuacji prawnej spadkobierców, którzy w spadku otrzymali gotówkę z umorzenia jednostek uczestnictwa przez spadkodawcę a podatników, którzy odziedziczyli jednostki uczestnictwa i zdecydowali się na ich umorzenie.

Należy również podkreślić, że koszt na nabycie jednostek uczestnictwa zostaje faktycznie i definitywne poniesiony już w momencie ich nabycia przez spadkodawcę. W tym momencie dochodzi do realizacji przesłanki faktycznego poniesienia i nie sposób zgodzić się, że spadkodawca, nie decydując się za życia na umorzenie jednostek uczestnictwa, nigdy nie nabył prawa do rozliczenia kosztów uznania przychodów.

\section{SuKCESJA PODATKOWA W DRODZE DZIEDZICZENIA} NA PODSTAWIE ART. 97 ORDYNACJI PODATKOWEJ

Jak wcześniej zostało wspomniane, wydając uchwałę w omawianej sprawie, NSA nie odniósł się do kwestii zastosowania art. 97 Ordynacji podatkowej, zgodnie z którym spadkobiercy podatnika przejmują przewidziane

${ }^{9}$ Konstytucja Rzeczypospolitej Polskiej z dnia 2 kwietnia 1997 r., Dz.U. z 1997 r. Nr 78, poz. 483. 
w przepisach prawa podatkowego majątkowe prawa i obowiązki spadkodawcy. W $₫ 2$ tego przepisu ustawodawca dodał zastrzeżenie, iż prawa niemajątkowe, które przysługiwały spadkodawcy w związku z prowadzoną działalnością gospodarczą, przechodzą na spadkobierców pod warunkiem dalszego prowadzenia tej działalności na ich rachunek ${ }^{10}$.

W stosunku do praw majątkowych, w art. $97 \$ 1$ ustawodawca zdecydował się więc na wprowadzenie sukcesji generalnej praw i obowiązków przewidzianych w przepisach prawa podatkowego. Wynika $\mathrm{z}$ tego, że spadkobiercy przejmują wszystkie prawa wynikające $\mathrm{z}$ prawa podatkowego bez względu na ograniczenia wynikające $\mathrm{z}$ innych przepisów prawa podatkowego $^{11}$. Istotą sukcesji generalnie jest także traktowanie spadkobierców jak podatnika, tj. spadkodawcy.

Problematyczne pod względem interpretacyjnym może okazać się wyodrębnienie w prawie podatkowym praw i obowiązków o charakterze majątkowym i niemajątkowym, jako że przepisy tej gałęzi prawa nie zawierają określeń tych pojęć. Chociaż $\mathrm{w}$ prawie podatkowym nie zostało wprost zdefiniowane pojęcie praw majątkowych, generalnie przyjmowanym w doktrynie kryterium podziału praw na majątkowe i niemajątkowe jest bezpośrednie uwarunkowanie interesem ekonomicznym podmiotu uprawnionego $^{12}$. Do praw majątkowych zalicza się więc między innymi prawo do nadpłaty, zwrotu podatku lub różnicy podatku naliczonego oraz prawo do rozliczenia straty w następnych okresach rozliczeniowych. Nieuznanie więc prawa do pomniejszenia przychodu o koszty poniesione przez spadkodawcę na nabycie jednostek uczestnictwa za prawo majątkowe, mimo, że spełnia podobne kryteria jak wyżej wymienione prawa, wydaje się dyskryminujące dla określonej grupy podatników.

Zgodnie z poglądem wyrażonym przez S. Babiarza, za prawo majątkowe należy również uznać ekspektatywy nabycia tego prawa, tj. sytuacje prawne rozumiane jako prawa majątkowe tymczasowe, zbywalne i podlegające ochronie prawnej. Za ekspektatywę prawa uznaje się „sytuację prawną, w której przynajmniej jedna z przesłanek koniecznych do nabycia

${ }^{10}$ Zob. szerzej A. Mariański, Kontynuacja działalności gospodarczej przez spadkobierców, cz. I, „Monitor Podatkowy” 2003, nr 9.

${ }^{11}$ A. Mariański, Prawa i obowiązki następców prawnych w prawie podatkowym, Warszawa 2001.

12 Tak np. S. Grzybowski (red.), Prawo cywilne, Warszawa 1981; uchwała NSA z 29 maja 2000 r., FPS 2/00; ONSA 2001, nr 1, poz. 2. 
prawa podmiotowego została już spełniona, a przynajmniej jedna (inna) przesłanka spełniona jeszcze nie została ${ }^{13}$.

Jako przykład takiej ekspektatywy autor podaje m.in. właśnie nabycie prawa do obniżenia przychodu uzyskanego z wykupu jednostek uczestnictwa przez fundusz kapitałowy w sytuacji, gdy jednostki te nabył spadkodawca, a ich zbywcą był spadkobierca. Należy pamiętać, że pojęcie ekspektatywy wywodzi się z prawa cywilnego i jest właściwe dla tej dziedziny prawa. Instytucja ekspektatywy, zdaniem przedstawicieli doktryny, pojawia się w związku z oczekiwaniem podmiotu na nabycie (powstanie) prawa podmiotowego.

W takiej sytuacji, jak wskazał NSA z wyroku z 11 października 2013 r. przesłankami obniżenia przychodu o wydatki na nabycie takich jednostek jest: 1) nabycie jednostek, 2) złożenie oferty ich wykupu, 3) zbycie jednostek, 4) złożenie zeznania podatkowego. Oczywiście nieprawidłowe jest więc stanowisko, często zajmowane przez sądy administracyjne, jakoby „zbycie jednostek przez spadkobiercę miało charakter następczy, samoistny, niepowiązany z realizacją określonego prawa majątkowego lub nawet ekspektatywy tego prawa przysługującego spadkodawcy, które mogłoby podlegać sukcesji na zasadach określonych w art. $97 \$ 1$ Ordynacji podatkowej ${ }^{14}$.

Niewątpliwie słusznym poglądem jest natomiast uznanie, że prawo do rozliczenia poniesionych kosztów, powstając za życia spadkodawcy, podlega sukcesji podatkowej zgodnie z art. $97 \$ 1$ Ordynacji podatkowej i przechodzi na spadkobiercę. Prawo to ma zdecydowanie majątkowy charakter - wpływa bowiem na interes ekonomiczny podmiotu uprawnionego. Jak już wcześniej wspomniano, sukcesja podatkowa polega na przejściu ogółu praw i obowiązków na spadkobiercę. Osoba taka jest, co prawda, innym podmiotem praw, jednak kontynuuje wykonywanie praw i obowiązków spadkodawcy. Wynika z tego, że jeżeli spadkobierca ponosi wydatki na nabycie jednostek uczestnictwa, a spadkobierca wstępuje w jego prawa i obowiązki na zasadzie sukcesji podatkowej, to w konsekwencji tych zdarzeń należy uznać, że na moment ustalania podstawy opodatkowania w podatku dochodowym spadkobierca poniósł koszty na nabycie jednostek. Sukcesji podatkowej podlega prawo do rozliczenia kosztu, które powstało za życia spadkodawcy, a może być uznane w momencie umorzenia jednostek.

${ }^{13}$ S. Babiarz, Następstwo prawne spadkobierców i zapisobierców zwykłych $w$ prawie podatkowym, Warszawa 2013.

${ }_{14}$ Tak np. NSA w wyroku z 10 lutego 2009 r., sygn. akt II FSK 1623/07 (publ. LEX nr 518745). 
W przypadku gdy umorzenia dokona spadkobierca, który przejął to prawo majątkowe, następuje rozliczenie owego kosztu. Stanowisko takie przedstawił również NSA w przytoczonym wcześniej wyroku z 11 października 2013 r., stwierdzając, że

dla bytu prawa majątkowego nie jest konieczna jego konkretyzacja pojmowana jako zaistnienie jeszcze za życia spadkodawcy zdarzenia skutkującego możliwością skorzystania z owego prawa. W tym ujęciu, prawem majątkowym jest także (bez wnikania w kwestię warunkowego charakteru czy też potencjalnego charakteru uprawnienia) prawo do pomniejszenia przychodu o koszty, które poniósł spadkodawca nabywając jednostki uczestnictwa w funduszu inwestycyjnym, przy przedstawieniu jednostek do wykupu funduszowi.

Inaczej niż w głosowanej uchwale, na gruncie tożsamego stanu faktycznego argumentował swoje stanowisko WSA w Warszawie ${ }^{15}$. W uzasadnieniu wyroku, skład orzekający uznał, iż w świetle przedstawionego stanu faktycznego oraz na gruncie art. $97 \$ 1$ O.p. należy uznać, że obowiązek uwzględnienia jako koszty uzyskania przychodów przy ustalaniu wysokości podstawy opodatkowania przy zbyciu jednostek uczestnictwa jako prawo majątkowe podlega sukcesji generalnej i przechodzi na spadkobierców, a art. 97 $\$ 1$ O.p. stanowi jedyną i wyłączną podstawę dla nabycia przez spadkobierców uprawnień po spadkodawcy. Pozytywnie należy ocenić również argumentację sądu, iż zaliczenie wydatków na nabycie tytułów uczestnictwa lub jednostek uczestnictwa w funduszach kapitałowych w poczet kosztów uzyskania przychodu z odkupienia tytułów uczestnictwa lub jednostek uczestnictwa w tychże funduszach, stanowi obowiązek o charakterze majątkowym mieszczący się w dyspozycji normy art. 97 O.p. i podlegający w związku z jej brzmieniem dziedziczeniu. Nie budzi bowiem wątpliwości, że wynika on z przepisów prawa podatkowego i spoczywał na spadkodawcy.

$\mathrm{Na}$ taki sam charakter art. 97 O.p. powoływał się również NSA w wyroku z dnia 20 września 2011 r. ${ }^{16}$ Mimo iż wyrok ten został wydany w odmiennej przedmiotowo sprawie, to argumentację sądu bez wątpienia można odnieść również do omawianego stanu faktycznego. W wyroku tym sąd stwierdził, iż

treść art. $97 \$ 1$ O.p. musi być interpretowana w sposób umożliwiający przejście na spadkobiercę prawa do zwrotu części zapłaconego podatku przez osobę fizyczną, która poniosła wydatki związane z budownictwem mieszkaniowym. Dlatego niedopuszczalne jest takie interpretowanie art. $97 \$ 1$ O.p., które ogranicza jego zakres,

${ }^{15}$ Wyrok WSA w Warszawie z 1 lutego 2013 r., III SA/Wa 1606/12, niepubl.

${ }^{16}$ I FSK 1370/10, niepubl. 
wyłączając możliwość złożenia wniosku, stanowiącego wymóg otrzymania zwrotu w myśl art. $5 \$ 1$ ustawy z 2005 r. o zwrocie osobom fizycznym niektórych wydatków związanych z budownictwem mieszkaniowym, przez spadkobiercę osoby, która dokonała wydatków związanych z budownictwem mieszkaniowym i na którą z tego tytułu wystawiono faktury. Pod pojęciem praw majątkowych, które stanowią przedmiot sukcesji, należy rozumieć prawo do zwrotu części wydatków poniesionych na zakup materiałów budowlanych wraz z wszelkimi elementami procesowymi warunkującymi skorzystanie z tego prawa. Należy podkreślić, że prawo do zwrotu realizowane poprzez złożenie wniosku stanowi prawo majątkowe jako całość.

Sąd zwrócił również uwagę, iż tylko taka wykładnia art. 97 O.p. jest zgodna $\mathrm{z}$ realizacją wartości konstytucyjnych, chronionych przez art. 21 ust. 1 i art. 64 ust. 1 ustawy zasadniczej.

4. WNIOSKI

Pomimo że glosowana uchwała jest korzystna dla podatników, nie można w pełni zgodzić się ze stanowiskiem zajętym przez sędziów Najwyższego Sądu Administracyjnego. Powołanie się przez sąd jedynie na wykładnię treści przepisów prawa materialnego (art. 22 ust. 1 i art. 23 ust. 1 pkt 38 w związku $\mathrm{z}$ art. 10 ust. 1 pkt 7, art. 17 ust. 1 pkt 3 i art. 30a ust. 1 pkt 2 u.p.d.o.f.) faktycznie doprowadziło, jak podkreślił sąd, do uznania opisanych wydatków za koszt uzyskania przychodów. Jednakże nie sposób zgodzić się, że w takim wypadku zasadne było całkowite pominięcie odwołania się do zasad ogólnych następstwa podatkowego wyrażonych w art. $97 \$ 1$ Ordynacji podatkowej. Rzeczywiście, zastosowanie w tej jednostkowej sprawie przepisów prawa materialnego prowadzi ostatecznie do tych samych rezultatów jak zastosowanie przepisów dotyczących sukcesji podatkowej. Niewątpliwie zasadne byłoby jednak odwołanie się do art. 97 Ordynacji podatkowej co pozwoliłoby na rozwianie wątpliwości podatników nie tylko w przypadku zaliczania przez spadkobiercę do kosztów uzyskania przychodów wydatków na nabycie jednostek uczestnictwa w funduszach kapitałowych poniesionych przez spadkodawcę, ale również między innymi rozliczania straty czy zaliczania jako koszty podatkowe wydatków poniesionych na nabycie towarów handlowych.

Jedną z cech sukcesji podatkowej w przypadku spadkobrania jest bowiem możliwość rozliczania kosztów poniesionych przez spadkodawcę. Jeżeli zaliczył on je do kosztów za swojego życia, to spadkobiercy kontynuujący działalność gospodarczą mają prawo do rozliczenia ewentualnej straty. W innym przypadku, zwłaszcza gdy koszt jest rozliczany w momencie uzyskania przychodu (zbycie papierów wartościowych, 
umorzenie jednostek uczestnictwa w funduszach inwestycyjnych), prawo do tego kosztu, które powstało jeszcze za życia spadkodawcy, przechodzi na spadkobierców. Wszelkie odstępstwa od tej zasady muszą mieć wyraźną podstawę prawną. W przeciwnym wypadku dochodziłoby bowiem do naruszenia praw spadkobierców ${ }^{17}$.

W głosowanej uchwale, $\mathrm{z}$ jednej strony NSA zanegował profiskalne podejście organów podatkowych, przyznając podatnikom prawo do odliczania wyżej opisanych kosztów, z drugiej zaś strony nie odwołał się do ogólnych zasad dotyczących sukcesji podatkowej wynikających z Ordynacji podatkowej, co niewątpliwie objęłoby szerszą grupę stanów faktycznych i miało zastosowanie dla liczniejszego grona podatników. Warto bowiem pamiętać, że uchwała składu siedmiu sędziów NSA nie tylko wiąże w danej sprawie, co wynika $z$ art. $187 \$ 1$ p.p.s.a. ${ }^{18}$, ale cechuje ją również tzw. ogólna moc wiążąca. Przejawia się ona w tym, że żaden skład sądu administracyjnego nie może rozstrzygnąć innej sprawy w sposób sprzeczny ze stanowiskiem zawartym w uchwale powiększonego składu NSA (art. 269 $\$ 1$ p.p.s.a.). Skład, który nie podziela wspomnianego stanowiska, może jedynie przedstawić dane zagadnienie odpowiedniemu składowi powiększonemu. W praktyce więc sytuacja spadkobierców, którzy chcą pomniejszyć przychód z tytułu odkupienia jednostek uczestnictwa o wydatki poniesione na ich nabycie, zarówno w stanie prawnym obowiązującym do 31 grudnia 2013 r. jak i w stanie prawnym aktualnie obowiązującym jest jednakowa i nie prowadzi do dyskryminacji w tym zakresie. Nie oznacza to jednak, jak wskazano powyżej, że glosowana uchwała zasługuje na pełną aprobatę. Aby jednoznacznie zakończyć wątpliwości podatników w zakresie sukcesji praw i obowiązków w drodze dziedziczenia, sąd powinien odwołać się przy orzekaniu do zasad wprost wynikających z omawianych przepisów Ordynacji podatkowej. Ułatwiłoby to ukształtowanie prawidłowej wykładni zasad sukcesji podatkowej w zakresie innych kosztów podatkowych.

17 A. Mariański, Rozliczanie kosztów podatkowych przez spadkobierców. Teza 2, „Pr. i P.” 2012, nr 10, s. 5-10.

${ }^{18}$ Ustawa z dnia 30 sierpnia 2002 r. Prawo o postępowaniu przed sądami administracyjnymi, Dz.U. z 2002 r. Nr 153, poz. 1270. 


\title{
BIBLIOGRAFIA
}

Babiarz S., Następstwo prawne spadkobierców i zapisobierców zwyklych w prawie podatkowym, Warszawa 2013.

Grzybowski S. (red.), Prawo cywilne, Warszawa 1981.

Mariański A., Glosa do wyroku NSA z 2.12.2011, II FSK 2557/10, „Glosa” 2013, nr 1.

Mariański A., Kontynuacja działalności gospodarczej przez spadkobierców, cz. I, „Monitor Podatkowy" 2003, nr 9.

Mariański A., Rozliczanie kosztów podatkowych przez spadkobierców. Teza 2, „Pr. i P.” 2012, nr 10.

Nykiel W., Mariański A. (red.), Komentarz do ustawy o podatku dochodowym od osób fizycznych, Warszawa 2015.

Szymański K.G., Krajewski M., Glosa do wyroku NSA z dnia 2 grudnia 2011 r., II FSK 2557/10., „Przegląd Podatkowy” 2012, nr 4.

\begin{abstract}
The article analyzes and evaluates the judgment issued by the Supreme Administrative Court on November 17 2014, which referred to the possibility of including tax costs by the heir of expenses for the acquisition of units incurred by the testator. Although the beneficial ruling for taxpayers deserves approval, it can not be accepted that the general principles of tax succession were omitted, as the court focused only on the material provision.
\end{abstract}

Keywords: gloss, tax expenditures, involving units, heir, bequeather 